\title{
Impact of applied irrigation regime during specified phenological stages on cropping and its' attributes of "Le-conte" pear
}

\author{
Ramzy G. Stino' ${ }^{1}$;. A. Abd El-Mohsen ${ }^{1}$; M. E. Shawky ${ }^{2}$; M. M. Yhia ${ }^{3}$; M. A. Abd-El-Wahab \\ ${ }^{1}$ Pomology, Fac. Agric., Cairo University \\ ${ }^{2}$ Soil, Water and Enviro. Fac. Agric., Cairo University \\ ${ }^{3}$ Horticultural Research Inst. Agric. Res. Cent. Giza, Egypt. \\ Corresponding author: mohmedabdelwahab50@yahoo.com
}

\begin{abstract}
This study was carried out during three successive seasons 2013, 2014 and 2015 on seventeen years old Le-Conte pear trees. The first season was considered to be on preliminary season to eliminate the residual effects of the previously used irrigation treatments. Pear growing season was split to four phenological stages (stage I beginning of flowering to final fruit set, stage II from initial fruit set to final fruit set, stage III final fruit set to harvesting and stage IV harvesting to leaf shed). However, control trees received $100 \%$ of crop water requirement during all stages while the remaining trees received three water regimes $(60,80$ and $120 \%$ of crop water requirement) applied at each of the phonological stages and then irrigated with the stayed stages were receiving optimal level of irrigation requirement $(100 \%)$ for the remaining stages. The fruit set $\%$, fruit abscission\%, yield (Kg), fruit characteristic (fruit weight (gm.), fruit firmness, juice TSS \% titratable acidity \%), chemical analysis (Leaf content of macro nutrients (nitrogen, phosphorous, potassium content (\%), magnesium, iron , zinc, manganese and copper contents $(\mathbf{m g} / \mathbf{l})$ and leaf content of photosynthetic pigments (chlorophyll $(\mathrm{a}, \mathrm{b})$ and carotenoids) parameters were assessed.

Results showed that enhancements of fruit set percentage were induced by applying $60 \%$ of the actual requirement during stage II, fruit abscission declined by increasing the applied water quantities during stage IV and producing significantly the highest yield per tree, fruit weight increase by increasing the applied water quantities during stage III, firmness and TSS increases with decreasing the actual requirement during any studied stages, the highest leaf nitrogen content was due to applying the highest regime during stage III, increasing potassium, phosphorus, magnesium, iron , copper and chlorophyll contents were attributed to the lowest regime when applied during stage II, leaf zinc and manganese content increased by applying the highest regime during stage II.
\end{abstract}

Key words: Le Conte pear- water regimes - fruit set - fruit abscission - fruit weight - firmness - . TSS chlorophyll - nitrogen - phosphorus - potassium - iron - zinc - manganese - copper

\section{Introduction}

Pear is one of the most important fruits grown worldwide. It ranks the sixth concerning the cultivated area. "Le Conte" is the main pear cultivar in Egypt. It resulted as a hybrid between (Pyrus Communis, L.) and (Pyrus Serotina, Rehd). The cultivated area reached 9404 feddans which produced about 58852 tons with an average production of 6.26 tons/feddan (Ministry of Agriculture, 2013) while the world an average production of 7.94 tons/feddan (Fao stat,2013).

Flowering is generally considered a critical period for a large number of crops. Water restrictions during this phenological stage can inhibit ovule fertilization (Hsiao, 1993), reducing drastically the final number of fruit and consequently the yield._Water stress that develops during the spring or early summer can have dramatic effects on, fruit set and fruit growth, because early season shoot growth and early development of fruit are primarily by cell division processes. Water stress that develops during mid-summer, i.e., after canopy development and fruit set, will have less effect on vegetative growth and fruit yield. Late season processes such as flower bud development, root growth, and nutrient uptake, reserve storage and winter acclimatization are affected by late season water stress (Kuroda et al., 1985).

On the other hand, the world faces very serious global warming, which will produce a general warming and significantly increase the evaporative demand and the irrigation requirement for crops. For this reason, irrigation efficiency is becoming increasingly important in arid and semi-arid regions with limited water resources. Therefore, it is necessary to adopt specialized and efficient methods of irrigation,. In order to achieve the twin objectives of higher productivity and optimum use of water (Gercek et al., 2009).

One of the options proposed for a more efficient use of irrigation water is the application of regulated deficit irrigation (RDI) (Mitchell et al., 1984), which is based on the restriction of water supplies during certain stages of crop development, when yield and fruit quality have low sensitivity to reduction in water, providing normal irrigation during the rest of the season, especially during the «critical periods» or 
phenological stages with a higher sensitivity to water deficit (Mitchell et al., 1984; Chalmers et al., 1986).

Effects of RDI on water savings, yield, water use efficiency (WUE) and quality in different crops and fruit trees have been widely reported since the $1980 \mathrm{~s}$ (Dong et al., 2006). RDI techniques have been successfully applied to many fruit trees such as peaches (Chalmers et al., 1981), pears (Chalmers et al., 1986; Mitchell et al., 1986), Asian pears (Behboudian et al., 1994) and grapefruits (Cohen and Goell, 1988).

Overall, the results on fruit trees showed that water deficits and the associated water stresses during developmental stages would not negatively affect fruit yield. Many researchers have reported effects of regulated water deficits on vegetative growth, flowering, fruit growth, and yield in different pear tree cultivars under different climatic conditions (Mitchell et al., 1984, 1986; Caspari et al., 1994; Marsal et al., 2000). Some investigators found that RDI techniques used from the early stages of fruit growth up to the end of shoot growth affected vegetative growth by inhibiting shoot development, but did not affect the final fruit size, number of fruit produced or yield (Chalmers et al., 1984; Li et al., 1989). Goldhamer et al. (2006) reported variations in the effects of water stress treatments applied at different times on the yield and yield components of almonds. RDI saved $25 \%$ of the summer irrigation water used in California but did not reduce the final yield in olive trees (Goldhamer, 1999). There was also no negative effect on loquat quality and yield with RDI treatments (Cuevas et al., 2007).

Fruit quality is an important factor for its market value. Application of inappropriate amounts of irrigation at incorrect time is waste of water resources and can lead to poor fruit quality. Since the 1990s, the effects of RDI on fruit quality and related soil water deficit index have been studied using both qualitative descriptions and quantitative indices (Behboudian and Mills, 1997). Some investigators revealed that RDI could improve fruit quality in terms of physical and chemical attributes (Liu et al., 2001; Verreynne et al., 2001). Li (1993) reported that deficit irrigation during fruit development and post-harvest in peach trees significantly reduced vegetative growth, but fruit production was not affected until the fourth consecutive year. Deficit irrigation in grapevines not only saved irrigation water by $50 \%$, but also increased the WUE greatly without any yield reduction and improved berry quality and taste (Dos Santos et al., 2007). To obtain the maximal pear yield and optimal fruit quality, it is necessary to understand the growth phases of trees, especially the most susceptible phase to irrigation.

According to Le et al., (1989) and Girona et al., (1997), Timing of water deficits was found to have important effects on productivity of fruit trees. On the other hand, excessive water may have adverse effects on fruit quality, since it increases vegetative growth, promoting nutritional imbalance and decreasing fruit dry mass (Liao and Lin, 2001; Jackson and Colmer, 2005).

One of the benefits of RDI its' importance in maintaining the fruit taste and quality (Li et al., 1989; Mills et al., 1996; Mpelasoka et al., 2000). Soluble solids content (SSC) and titratable acidity (TA) warrant particular attention due to their importance in fruit taste (Crisosto et al., 1994).

The effect of irrigation level on leaf mineral content was reported by numerous researchers as Abd El-Nasser and El-Shazly, (2000) and Mikhael and Mady, (2007) on apple. They mentioned that, there is a general significant positive effect on the percent of $\mathrm{N}, \mathrm{P}$ and $\mathrm{K}$ in leaves due to increasing available soil water. Similarly, Khalil, (2004) on olive found that, $\mathrm{K}$ content in leaves was significantly reduced by decreasing irrigation rate. Channel and Ranbirsingh (1992) on mango and Ahmed (1994) on pomegranate trees indicated that, leaf content of $\mathrm{Ca}$ was greater with increasing irrigation levels.

Photosynthetic pigments content in leaves was significantly higher in the "Canino" apricot and "Anna" apple trees grown under high irrigation rate (El- Seginy, 2006, Mikhael, and Mady, 2007). This increment in leaf pigment concentration could be attributed to increasing of macronutrient uptake, especially $\mathrm{N}$ and $\mathrm{Mg}$ as a consequence of improved soil moisture under irrigation (Khattab, et al., 2011)

The main objective of the present investigation was to assess the impact of applied water regimes during specified phenological stages on yield and its' attributes , and the accompanying changes in leaf content of micro \& macro nutrients photosynthetic pigments of "Le-Conte" pear trees.

\section{Material and methods}

\section{Experimental conditions and plant material}

The present experiment was performed during 2013, 2014 and 2015 in 2.5 feddans plot at a private orchard, located in in at El-Khatatba district, Minufiya governorate. Mature "Le-Conte" pear trees budded on Pyrus communis rootstock, spaced $5 \times 5$ $\mathrm{m}$, vase trained and subjected to cultural practices recommended by the Ministry of agricultural, with an average height of $3.5 \mathrm{~m}$, and ground cover of about $85 \%$ were adopted. Trees were drip irrigated using two drip irrigation lines for each row.

Soil physical and chemical properties were determined in the laboratory of the Soil, Water and Environmental Res. Inst. according to the methods described by Jackson (1973) and the results are summarizing in Table (1). 
Table 1. Physical and chemical properties of the orchard soil.

\begin{tabular}{|c|c|c|c|}
\hline & \multirow{3}{*}{ Parameter } & \multicolumn{2}{|c|}{ Soil sample depth } \\
\hline & & $0-30 \mathrm{~cm}$ & $30-60 \mathrm{~cm}$ \\
\hline & & \multicolumn{2}{|l|}{ Value } \\
\hline \multirow{6}{*}{$\begin{array}{l}\text { Physical } \\
\text { properties }\end{array}$} & Fine sand \% & 40.43 & 39.28 \\
\hline & Coarse sand \% & 45.18 & 48.00 \\
\hline & Silt \% & 5.66 & 3.35 \\
\hline & Clay \% & 8.73 & 9.37 \\
\hline & Texture class & L. Sand & L. Sand \\
\hline & & \multicolumn{2}{|l|}{ loamy } \\
\hline \multirow{11}{*}{$\begin{array}{l}\text { chemical } \\
\text { properties }\end{array}$} & Ec $(\mathrm{ds} / \mathrm{m})$ & 9.25 & 3.98 \\
\hline & $\mathrm{Ca}++(\mathrm{me} / \mathrm{l})$ & 19.5 & 8.5 \\
\hline & $\mathrm{Mg}++$ & 53.5 & 25.5 \\
\hline & $\mathrm{Na}+$ & 16.4 & 3.5 \\
\hline & $\mathrm{K}+$ & 0.96 & 0.56 \\
\hline & Co3-- & - & - \\
\hline & $\mathrm{HCo} 3-$ & 5 & 4 \\
\hline & $\mathrm{Cl}-$ & 74.5 & 29 \\
\hline & So4-- & 10.86 & 5.06 \\
\hline & $\mathrm{PH}$ & 7.82 & 7.79 \\
\hline & $\mathrm{Sp} \%$ & 36.7 & 31.8 \\
\hline
\end{tabular}

The experimental design of each irrigation treatment was 4 standard experimental plots distributed randomly in blocks. The standard plot was made up of 15 trees, organized in 4 adjacent rows. The 3 central trees of the middle row were devoted for assessments (each tree acting as a replicate, and the other 12 trees were guard trees.

\section{Irrigation treatments:}

The present research study was initiated in 2013and extended for three successive growing seasons. The first season was considered to be a preliminary season to eliminate the residual effects of the previously used irrigation treatments. Pear growing season was split to four phonological stages as presented in Table (2). However, control trees received $100 \%$ of irrigation requirement during all stages while the remaining trees received three water regimes (60, 80 and $120 \%$ of irrigation requirement) applied at each of the phonological stages and then irrigated was applied for the remaining stages with $100 \%$ of the water requirements. After the last phonological stage, irrigation was withhold till the commencement of stage 1

Table 2. The adopted phonological stages

\begin{tabular}{|c|c|c|}
\hline Phonological stage & Date & $\begin{array}{l}\text { No. of days from beginning } \\
\text { of flowering }\end{array}$ \\
\hline stage beginning $10 \%$ flowering to final fruit set (six weeks & $07 / 03$ & \\
\hline after petal full) (F-I.FS) & $15 / 4 / 2014-15$ & 37 days \\
\hline $\begin{array}{ll} & \text { from initial fruit set (three weeks after petal full) to } \\
\text { stage } & \text { final fruit set } \\
\text { II } & \text { (I.FS - F.FS) } \\
\end{array}$ & $\begin{array}{ll}15 / 04 & \text { to } \\
7 / 05 / 2014 & \\
\end{array}$ & 21 days \\
\hline $\begin{array}{l}\text { stage } \\
\text { III final fruit set to harvesting (F.FS- H) }\end{array}$ & $\begin{array}{ll}7 / 05 & \text { to } \\
15 / 08 / 2014 & \\
\end{array}$ & 83 days \\
\hline $\begin{array}{l}\text { Stage } \\
\text { IV } \quad \text { harvesting to natural defoliation or leaf shed (H - D) }\end{array}$ & $\begin{array}{ll}15 / 08 & \text { to } \\
1 / 11 / 2014 & \\
\end{array}$ & 75 days \\
\hline
\end{tabular}

The applied levels of irrigation were calculated as daily crop water requirements (liter/tree/day), as follow:

$1-$ The 1 st irrigation level (optimum rate) $=100 \%$ of the crop water requirement (CWR), this amount of water was calculated theoretically from the "TAHRIR" meteorological data of the planting region.

2 - The 2 nd irrigation level (high rate) $=120 \%$ of the CWR.
3 - The 3rd irrigation level (moderate rate $)=80 \%$ of the CWR.

4 - The 4th irrigation level (low rate) $=60 \%$ of the CWR.

The relative requirements were applied by changing the number and or discharge of emitters used. Water requirements were calculated as elucidated by Karmeli and Keller (1975):

IR = (Se.SL.ETo.Kc.Kr/Ea)*(1/1-Lr)

IR = Daily irrigation requirements 


$$
\begin{array}{ll}
\mathrm{Se} . & =\begin{array}{l}
\text { Plant area (Plant distance on lateral* } \\
\text { between laterals) }
\end{array} \\
\mathrm{ETo}= & \begin{array}{l}
\text { Daily reference evapotranspiration on } \\
\text { mm/day }
\end{array} \\
\mathrm{Kc}= & \begin{array}{l}
\text { coefficient factor for pear trees (Allen, } \text { et } \\
\text { al., } 1998) .
\end{array} \\
\mathrm{Kr}= & \text { Reduction coefficient Gc/0.85 } \\
\mathrm{Gc}= & \text { Ground cover (area of tree canopy) } \\
\mathrm{Ea} \quad= & \text { Efficiency of irrigation system }(80-90 \%) \\
\mathrm{Lr}= & \text { Leaching requirements = Eci/Ecd } \\
\mathrm{Eci}= & \text { Electrical conductivity of irrigation water } \\
\mathrm{Ecd} & =\text { Electrical conductivity of drainage water }
\end{array}
$$

Whereas, The ETo value was calculated using the atmospheric conditions data prevailing at El-Khatatba district. Crop irrigation requirements were scheduled weekly according to daily ETo, Since, Penman Monteith method was used to calculate ET crop for pear trees in the district during 2014 and 2015 seasons of study using CROPWAT model (Smith 1991).

$$
\begin{aligned}
& \mathrm{ETo}=\frac{0.408 \Delta(\mathrm{Rn}-\mathrm{G})+\gamma[900 /(\mathrm{T}+273] \mathrm{U} 2(\mathrm{es}-\mathrm{ea})}{\Delta+\gamma(1+0.34 \mathrm{U} 2)} \\
& \text { ETo }=\text { reference evapotranspiration, } \mathrm{mm} / \text { day } \\
& \mathrm{Rn}=\text { net radiation }(\mathrm{MJm}-2 \mathrm{~d}-1) \\
& \mathrm{G}=\text { soil heat flux (MJm-2d-1) } \\
& \Delta=\text { slope vapor pressure and temperature } \\
& \text { curve }\left(\mathrm{kPa}{ }^{\circ} \mathrm{C}-1\right) \\
& \Gamma=\text { psychrometric constant }\left(\mathrm{kPa}{ }^{\circ} \mathrm{C}-1\right) \\
& \mathrm{U} 2=\text { wind speed at } 2 \mathrm{~m} \text { height }(\mathrm{ms}-1) \\
& \text { es-ea }=\text { vapor pressure deficit }(\mathrm{kPa}) \\
& \mathrm{T}=\text { daily air temperature at } 2 \mathrm{~m} \text { height }\left({ }^{\circ} \mathrm{C}\right)
\end{aligned}
$$

Crop coefficient (KC) value was used for quantifying crop water use. It was calculated from the equation: $\mathrm{KC}=\mathrm{ETc} / \mathrm{ETo}$; where ETc is ETe/ETo the actual water consumptive use and ETo is the reference (potential evapotranspiration).

The correction coefficient for ground cover was according to Fereres and Goldhmaer (1990).

To unify the applied nutrients, application was done manually on weekly basis

\section{Assessments \\ 1. Fruit Set \%}

For each considered tree four scaffold branches were chosen at each of the four directions and tagged. The branches were of similar diameter and spur load as much as possible. At full bloom the number of flowers born on each branch was counted and at the fruit set stage (three weeks after full bloom) the number of set (fruitlets) born on each branch were counted. The fruit set \% was calculated by the following equation according to Westwood (1978) Percentage of fruit set $=$ Number of fruit set $/$ Total number of flowers*100. (On four

\section{Fruit abscission \%}

at harvests i.e. when fruits reached the maturity stage as previously described by ElAzzouni et al., (1975), the number of retained fruits on each tagged branch was counted and the abscission \% was calculated according to the following equation

Fruit abscission\%: number of all harvested fruits / number of fruit set $* 100$ (According to Westwood, 1978).

\section{Yield}

When fruits reached the maturity stage according to El-Azzouni et al., (1975), the number of fruits born on each tree were counted and multiplied by the average fruit weight born on that specific tree taken from a representing sample of ten fruits.

\section{Fruit characteristic}

At maturity, a representing sample of ten fruits was harvested from each considered tree and the following were assessed:

Fruit weight (gm.) using a digital scale, fruit firmness (lb/inch2) using a pressure tester, juice TSS $\%$ using a hand refractometer, and juice titratable acidity\% as malic acid, A.O.A.C (1990).

\section{Chemical analysis \\ a. Leaf content of macro nutrients}

From each of the replicates that were devoted for chemical analysis a representing sample of thirty leaves born on the current season growth was taken in mid-July of each season and the leaves were washed with tap water and oven dried at $60{ }^{\circ} \mathrm{C}$. A 0.5 gram of the dried samples was digested using the $\mathrm{H}_{2} \mathrm{SO}_{4}$ and $\mathrm{H}_{2} \mathrm{O}_{2}$ as previously described by Cottenie (1980). The extract was used to determine the following minerals:

Nitrogen content (\%) in the digested solution by the modified microkjeldahl method as described by Plummer (1971). Phosphorous content\% determined calorimetrically according to the method of Jackson (1958). Potassium content (\%) against a standard using flame-photometer (Piper, 1950). Calcium and magnesium contents (mg/l) by using Atomic Absorption Spectrophotometer, Pye Unican SP1900, According to Brandifeld and Spincer (1965).

\section{b. Leaf content of photosynthetic pigments:}

The method used for the quantitative determination of chlorophyll according to (Vernon and Selly, 1966) was adopted. One gram aliquot of fresh leaves was cut into small pieces. The pigments were extracted by grinding the cut tissue with suitable amount of glass powder in mortar using 100 $\mathrm{ml}$ of $80 \%$ aqueous acetone $(\mathrm{v} / \mathrm{v})$. The homogenate was transferred quantitatively to a Buchner filter with Whatman No. 1 filter paper. The filtrate was transferred quantitatively to $100 \mathrm{ml}$ volumetric flask and made up to a total volume of $100 \mathrm{ml}$ using $80 \%$ acetone. 
The optical density of the plant extract was measured using spectrophotometer of two wave lengths (649 and $665 \mathrm{~nm}$ ). These are positions in the spectrum where maximum absorption by chlorophyll (a) and (b) occurs. The concentrations of chlorophyll (a), (b) and total chlorophyll in leaf plant tissue were calculated using the equations mentioned by Vernon and Selly, (1966).

$\mathrm{Mg}$ chlorophyll (a) / g tissue $\quad=11.63(\mathrm{~A} 665)-$

2.39(A649).

Mg chlorophyll (b) / g tissue $=20.11($ A649) -

5.18(A665).

$\mathrm{Mg}$ chlorophyll $(\mathrm{a}+\mathrm{b}) / \mathrm{g}$ tissue $=6.45(\mathrm{~A} 665)$

+17.72 (A649).

For carotenoids, the concentration was determined according to

(Lichtentahler 1987) equation:

$\mathrm{Car}=1000 \times \mathrm{OD}_{470}-1.82 \mathrm{C}_{\mathrm{a}}-85.02 \mathrm{C}_{\mathrm{b}} / 198=$

$\mathrm{mg} / \mathrm{g}$ fresh weight.

\section{Statistical analysis:}

Split plot design was adopted for the experimental design. The statistical analysis of the present data was carried out according to Snedecor and Chocran (1980). Averages were compared using.
Least Significant Difference (LSD) test according to Duncan (1955) at probability of $0.5 \%$ using MSTAT program.

\section{Results and Discussion}

Fruit set and Abscission \%

Compared with control and remaining treatments, it was found that applying $60 \%$ of the actual irrigation requirements during stage II was the most effective treatment in inducing significantly the highest fruit set percentage. On the contrary statistically the lowest fruit set percentage was dedicated to applying highest irrigation rate during stage $I$ in both seasons and the application of the lowest rate during stage IV in the second season only (Table, 3).

As for the lowest significant percentage of fruit abscission it was achieved due to application of $120 \%$ of the actual water requirements during stage IV. Whereas application of $60 \%$ of the actual water requirements during stages IV \& I for both studied seasons respectively, induced statistically the highest percentages for this parameter. (Table, 3 ).

Table 3. Effect of water regime on initial fruit set and abscission percentage.

\begin{tabular}{llllll}
\hline & \multicolumn{2}{l}{ Initial fruit set (\%) } & \multicolumn{2}{l}{ Fruit abscission (\%) } \\
\hline $\begin{array}{l}\text { \% of actual } \\
\text { requirements }\end{array}$ & Phenological stages & 2014 & 2015 & 2014 & 2015 \\
\hline Control 100\% & during all stages & 5.99 & 7.56 & 53.78 & 81.26 \\
\hline \multirow{5}{*}{$120 \%$} & stage I (F-I.FS) & 3.88 & 5.35 & 51.92 & 78.59 \\
\cline { 2 - 6 } & stage II (I.FS - F.FS) & 5.61 & 12.16 & 72.31 & 83.80 \\
\cline { 2 - 6 } & stage III (F.FS- H) & 4.91 & 6.58 & 55.84 & 85.74 \\
\cline { 2 - 6 } & stage IV (H - D) & 5.57 & 8.84 & 35.42 & 68.68 \\
\hline \multirow{5}{*}{$80 \%$} & stage I (F-I.FS ) & 5.96 & 13.39 & 62.97 & 91.91 \\
\cline { 2 - 6 } & stage II (I.FS - F.FS) & 5.48 & 7.21 & 75.51 & 87.75 \\
\cline { 2 - 6 } & stage III (F.FS- H) & 5.92 & 11.78 & 58.97 & 84.33 \\
\cline { 2 - 6 } & stage IV (H - D) & 5.75 & 6.37 & 72.73 & 82.74 \\
\hline \multirow{3}{*}{$60 \%$} & stage I (F-I.FS ) & 5.31 & 13.96 & 39.66 & 95.24 \\
\cline { 2 - 6 } & stage II (I.FS - F.FS) & 7.14 & 15.72 & 67.36 & 77.15 \\
\cline { 2 - 6 } & stage III (F.FS- H) & 5.71 & 10.71 & 52.87 & 92.82 \\
\cline { 2 - 6 } & stage IV (H - D) & 4.20 & 5.12 & 76.33 & 92.81 \\
\hline LSD at 0.05 & & 0.13 & 0.79 & 0.45 & 0.80 \\
\hline
\end{tabular}

Previous reports by Nikbakht, et al., (2011) on olive, Khattab,et al., (2011) on pomegranate and Eid et al., (2013) on apricots illustrated drastic decreases in fruit set due to water stress. Earlier reports by Hsiao, (1993) clarified that the effect of water stress on crop reduction is due to inhibition of ovule fertilization.

In addition, results illustrated that applying $60 \%$ of the actual irrigation requirements during stage II inducing significantly the highest fruit set. This finding was noticed to be accompanied by mark able increases in potassium, phosphorus and magnesium as shown in tables $(7,8)$.
Potassium aids in building and moving carbohydrates from leaves to fruits and encouraging the biosynthesis of cellulose which positively strengthens the cell walls (Manjula Nathan, 2009). Phosphorus aids in forming phospholipids (Greamer and Bostock, 1986) and assists in enzyme activation and photosynthesis (Manjula Nathan, 2009). Mg is necessary for chlorophyll synthesis (Mengal and Kirkby, 1982) Thereby increases in the leaf content of those macro-nutrients might be the cause of increasing and or decreasing abscission.

Application of $60 \%$ of the actual water requirements during stages IV \& I for both seasons 
respectively induced statistically the highest abscission percentages

This results are in agrement with George and Nissen ' (1988); on apple and García-Tejero et al., (2010) on citrus and Khattab, et al., (2011) on pomegranate.

Abscission is an active physiological process that occurs through the dissolution of cell walls at predetermined positions ' the abscission zones, often is related to stress and senescence (Taylor and Whitelaw ، 2001).Also, under water deficit causes loss of calcium and pectin from the wall of separation layer cells presumably leading to the dissolution of the pectin-rich middle lamella, weakening the cell wall and leading to disintegration of abscission zones tissues (Addicott, 1982; Tripathi et al., 2008).

Moreover, water stress causes closure of stomata inducing lower photosynthetic (Kramer, 1995). This leads to decreasing the net resulting assimilates, Thereby increasing competition between developing fruitlets ended by higher abscission.

\section{Yield and its' attributes}

Results in table (4) illustrates that, increasing the rates applied to $120 \%$ of actual water requirements during (stage IV) in both seasons produced significantly the highest yield per tree. Whereas, the lowest yield was dedicated to reducing the applied water regime to $60 \%$ of actual water requirements during stages IV in both seasons of the investigation respectively.

In this respect, Küçükyumuk et al. (2013) on apples, Khattab et al. (2011) on pomegranate, Eid et al., (2013) on apricot attained results of similar trends.

Moderate water stress was found to improve the completion of flower bud development ، resulting in higher flower intensity and fruit set in subsequent seasons (Mitchell et al., 1989). While, severe postharvest water stress decreased the productivity in the subsequent year (Torrecillas et al., 2000; Naor et $a l ., 2005)$, this was due to reduced flowering intensity (Girona et al., 2003) and lower fruit set (Ruiz-Sanchez et al., 1999; Torrecillas et al., 2000; Girona et al., 2003). The lower fruit set was attributed to reduced pollen vitality (Ruiz-Sanchez et al. 1999), and delayed flower bud development (Naor et al., 2005).

\section{Physical attributes:}

With respect to the average fruit weight, it amounted to statically its' highest magnitude when using the regime of $120 \%$ of the actual irrigation requirements during stage III in both seasons. On the contrary statistically the highest negative effect was due to applying the lowest rate during stages III \&I for both seasons respectively (table 4).

Table 4. Effect of water regime on yield/tree and average fruit weight.

\begin{tabular}{llllll}
\hline & & \multicolumn{2}{l}{ yield/tree (kg) } & \multicolumn{2}{c}{ fruit Weight (gm) } \\
\hline \% of actual requirements & Phenological stages & 2014 & 2015 & 2014 & 2015 \\
\hline Control 100\% & during all stages & 113 & 35.67 & 234 & 251 \\
\hline \multirow{4}{*}{$120 \%$} & stage I (F-I.FS) & 116 & 46.67 & 267 & 278 \\
& stage II (I.FS - F.FS) & 140 & 69.33 & 225 & 249 \\
& stage III (F.FS- H) & 171 & 78.67 & 273 & 333. \\
& stage IV (H - D) & 186 & 127.83 & 257 & 275 \\
\hline \multirow{5}{*}{$80 \%$} & stage I (F-I.FS ) & 138 & 29.67 & 224 & 200 \\
& stage II (I.FS - F.FS) & 113 & 55.33 & 230 & 213. \\
& stage III (F.FS- H) & 138 & 51.50 & 210 & 277 \\
& stage IV (H - D) & 146 & 36.33 & 212 & 242 \\
\hline \multirow{5}{*}{$60 \%$} & stage I (F-I.FS ) & 97 & 28.33 & 267 & 177 \\
& stage II (I.FS - F.FS) & 125 & 98.67 & 256 & 264 \\
& stage III (F.FS- H) & 157 & 46.00 & 176 & 258 \\
& stage IV (H - D) & 62 & 24.17 & 229 & 183 \\
\hline LSD at 0.05 & & 1.14 & 1.79 & 1.13 & 0.80 \\
\hline
\end{tabular}

These results are in agreement with Abd El-Messeih and Gendy (2009) on "Le-Conte" pear and Küçükyumuk et al. (2013) on apple.

These results might have been induced due to negative effects exerted by deficit water on reproductive cell division stage which lasts 30-40 days after full bloom (Westwood, 1993) leading to smaller fruits ending to lower yield and vice versa. Data in Table (5) cleared that statistically the firmest fruits were dedicated to applying $80 \%$ of the irrigation requirements stage I in both seasons. On the contrary, significantly the least fruit firmness was attained by using highest irrigation dose (120\%) during stage (I) in both seasons.

These results are in harmony with Ali (2006) on peach, Kandil and El-Feky (2006) on apricot and Mikhael and Mady (2007) and Küçükyumuk et al. (2013) on apple fruit.

The increase in fruit firmness of stressed trees could be an artifact of fruit size decreases as a direct impact of irrigation deficit. The firmness of apples was found to increase with decrease in fruit weight (Ebel et al. 1993)

\section{Chemical attributes}


Table 5. Effect of water regime on average fruit firmness, TSS and fruit acidity.

\begin{tabular}{llllllll}
\hline & \multicolumn{2}{c}{ fruit firmness (lb/inch2 ) } & TSS & \multicolumn{2}{l}{ juice acidity } \\
\hline $\begin{array}{l}\text { \% of actual } \\
\text { requirements }\end{array}$ & Phenological stages & 2014 & 2015 & 2014 & 2015 & 2014 & 2015 \\
\hline Control 100\% & during all stages & 16.22 & 19.83 & 13.17 & 12.33 & 0.015 & 0.019 \\
\hline \multirow{3}{*}{$120 \%$} & stage I (F-I.FS) & 14.51 & 18.49 & 13.33 & 12.33 & 0.013 & 0.021 \\
& stage II (I.FS - F.FS) & 15.82 & 20.51 & 13.5 & 13.00 & 0.012 & 0.015 \\
& stage III (F.FS- H) & 15.72 & 19.75 & 12.33 & 11.67 & 0.013 & 0.015 \\
& stage IV (H - D) & 15.47 & 19.42 & 13.33 & 12.67 & 0.012 & 0.016 \\
\hline \multirow{3}{*}{$80 \%$} & stage I (F-I.FS ) & 16.97 & 21.38 & 13.67 & 12.00 & 0.013 & 0.019 \\
& stage II (I.FS - F.FS) & 15.59 & 19.90 & 13.33 & 13.33 & 0.016 & 0.021 \\
& stage III (F.FS- H) & 16.21 & 19.90 & 13.83 & 13.00 & 0.011 & 0.017 \\
& stage IV (H - D) & 15.05 & 20.28 & 14.01 & 12.40 & 0.015 & 0.016 \\
\hline \multirow{3}{*}{$60 \%$} & stage I (F-I.FS ) & 15.67 & 20.9 & 13.33 & 13.33 & 0.016 & 0.018 \\
& stage II (I.FS - F.FS) & 15.59 & 19.65 & 14.17 & 14.33 & 0.017 & 0.018 \\
& stage III (F.FS- H) & 16.51 & 20.40 & 12.83 & 13.33 & 0.015 & 0.017 \\
\hline LSD at 0.05 & stage IV (H - D) & 16.24 & 19.42 & 12.83 & 12.50 & 0.012 & 0.019 \\
\hline
\end{tabular}

Application of $60 \%$ from actual water requirements during stage $I$ in both seasons was the most effective in inducing statistically the highest TSS\%. On the contrary, significantly the lowest TSS $\%$ was dedicated to the application of $120 \%$ during stage III in both seasons (table 5).

In general, Ali et al. [1998] on apple, Hussein [2004] on pear and Abd El-Samad [2005] on guava achieved comparable findings in this concern.

Higher accumulation of sugars in early water stressed fruits was clarified by Kramer, (1983) to be as a result of enhancement of starch to sugar conversion due to this stress. Also our findings declared higher levels of both $\mathrm{K} \& \mathrm{P}$ due to water stress at stage II both are known to play pivotal roles in enhancing TSS formation (Jivan and Sala, 2014)

The results in table (5) showed that applied water regimes did alter the juice acidity in both of the considered seasons.
On the contrary, findings achieved by both Lawand and Patil (1996) and Shailendra and Agrawal (2005) on pomegranate declared significant effects of applied water regimes on juice acidity

\section{Photosynthetic pigments}

In general, the highest statistical leaf content of photosynthetic pigments was attributed to the lowest regime $(60 \%)$ when applied during stage II. This was untrue for chlorophyll $\mathrm{b}$ content in the second season for the utmost statistically effective regime was $80 \%$ of the requirements during stage III. The $60 \%$ application during stage II ranked the second with significant differences. Whereas, significantly the lowest leaf contents were dedicated to the application of the highest regime during stage III in both seasons (table 6)

Table 6. Effect of water regime on leaf Chlorophyll a,b and carotenoids content.

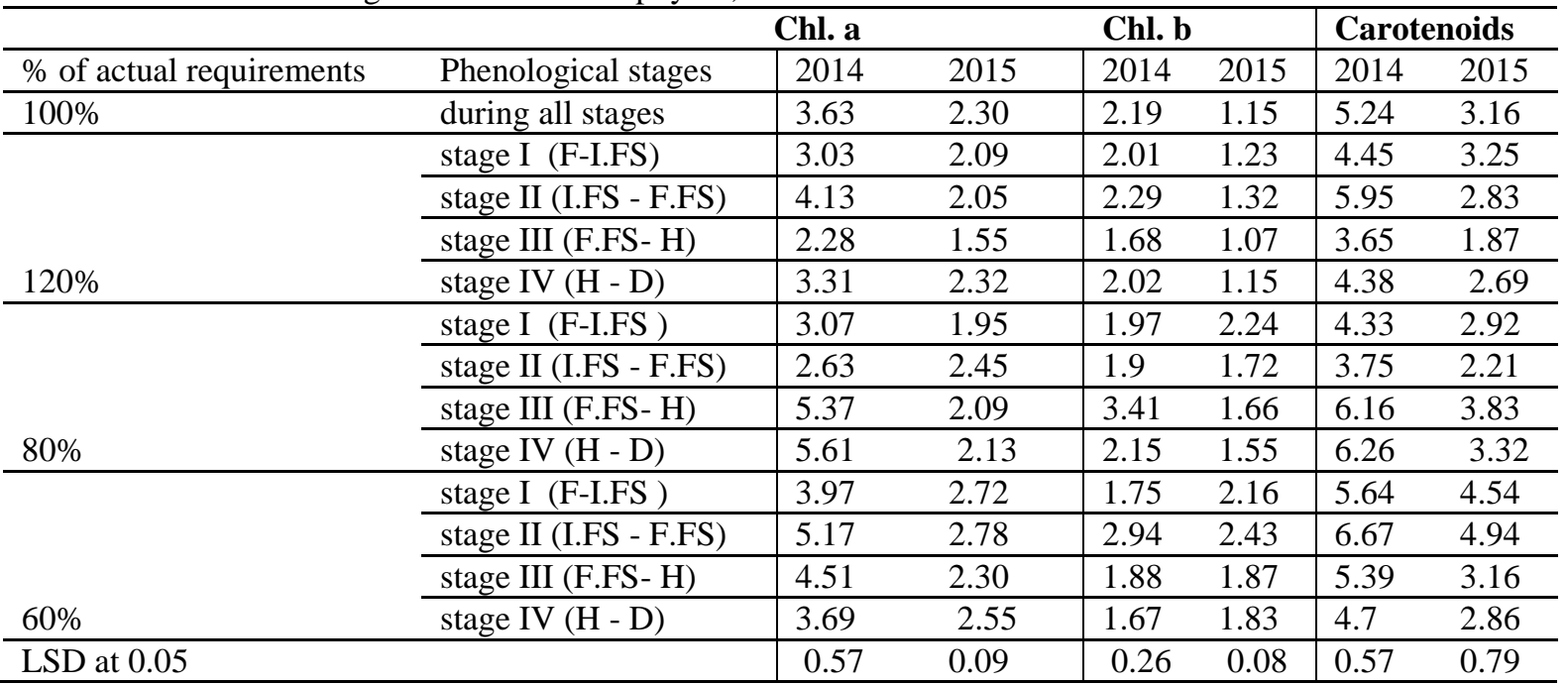


Mensha et al. (2006) found that drought stress caused leaf chlorophyll to increase. Contradicting results were found by Pirzad et al., (2011) as they declared no differences in chlorophyll $\mathrm{a}, \mathrm{b}$ due to in irrigation, at 100 and $55 \%$ field capacity.

Statistically the highest leaf content of photosynthetic pigments was attributed to the lowest regime when applied during stage II. This result may be due to associated increases in leaf, magnesium, which is necessary for chlorophyll synthesis, (Mengal and Kirkby, 1982).

\section{b. Leaf mineral content}

Statistically the highest leaf nitrogen content was due to applying the highest regime during stage III in both seasons. Whereas applying the same irrigation regime during stage I in both seasons induced significantly the lowest nitrogen content (table 7)

Table 7. Effect of water regime on leaf nitrogen and phosphorus content.

\begin{tabular}{llllll}
\hline & \multicolumn{2}{c}{ Nitrogen \% } & & \multicolumn{2}{c}{ Phosphorus \% } \\
\hline $\begin{array}{l}\text { \% of actual } \\
\text { requirements }\end{array}$ & Phenological stages & 2014 & 2015 & 2014 & 2015 \\
\hline Control 100\% & during all stages & 1.58 & 2.38 & 0.17 & 0.33 \\
& stage I (F-I.FS) & 1.33 & 1.36 & 0.14 & 0.28 \\
$120 \%$ & stage II (I.FS - F.FS) & 1.67 & 2.76 & 0.17 & 0.30 \\
& stage III (F.FS- H) & 1.76 & 3.14 & 0.16 & 0.31 \\
& stage IV (H - D) & 1.70 & 2.75 & 0.16 & 0.33 \\
\hline \multirow{4}{*}{$80 \%$} & stage I (F-I.FS ) & 1.52 & 2.44 & 0.21 & 0.31 \\
& stage II (I.FS - F.FS) & 1.49 & 2.50 & 0.21 & 0.32 \\
& stage III (F.FS- H) & 1.55 & 2.40 & 0.20 & 0.34 \\
$60 \%$ & stage IV (H - D) & 1.60 & 2.75 & 0.22 & 0.45 \\
\hline & stage I (F-I.FS ) & 1.40 & 1.52 & 0.25 & 0.45 \\
& stage II (I.FS - F.FS) & 1.49 & 1.75 & 0.30 & 0.50 \\
\hline LSD at 0.05 (season & 2014) is & 1.42 & 1.89 & 0.25 & 0.46 \\
\hline
\end{tabular}

Phosphorus content was statistically at its' highest magnitude when trees were subjected to the lowest irrigation regime during stage II. Increasing the applied water quantities to $120 \%$ of the actual requirements during stage I resulted in the least content in both seasons. Statistically equal contents in the second season were dedicated to applying same quantities during the remaining stages, applying $80 \%$ during stages I, II and III (table 7)
Data in Table (8) clear that lowest irrigation regime $(60 \%)$ added during stage II significantly induced highest leaf potassium content. Increasing the applied water quantities to 80 or $120 \%$ of the requirements during stage I resulted in significantly the lowest contents in both seasons. However these parameters were decreased by increasing the amount of water applied for the same stage to reach it utmost with the $120 \%$ application at same

Table 8. Effect of water regime on leaf potassium and magnesium content.

\begin{tabular}{llllll}
\hline & \multicolumn{2}{c}{ Potassium } & \multicolumn{2}{c}{ Magnesium \% } \\
\hline $\begin{array}{l}\text { \% of actual } \\
\text { requirements }\end{array}$ & Phonological stages & 2014 & 2015 & 2014 & 2015 \\
\hline Control 100\% & during all stages & $\mathbf{1 . 5 9}$ & $\mathbf{1 . 2 5}$ & 0.23 & $\mathbf{0 . 4 8 8}$ \\
\hline \multirow{5}{*}{$120 \%$} & stage I (F-I.FS) & 1.21 & 0.98 & 0.16 & 0.407 \\
\cline { 2 - 6 } & stage II (I.FS - F.FS) & 1.40 & 1.09 & 0.24 & 0.492 \\
\cline { 2 - 6 } & stage III (F.FS- H) & 1.35 & 1.50 & 0.17 & 0.499 \\
\cline { 2 - 6 } & stage IV (H - D) & 1.30 & 1.43 & 0.27 & 0.497 \\
\hline \multirow{5}{*}{$80 \%$} & stage I (F-I.FS ) & 1.21 & 1.03 & 0.21 & 0.459 \\
\cline { 2 - 6 } & stage II (I.FS - F.FS) & 1.40 & 1.09 & 0.28 & 0.480 \\
\cline { 2 - 6 } & stage III (F.FS- H) & 1.35 & 1.50 & 0.27 & 0.513 \\
\cline { 2 - 6 } & stage IV (H - D) & 1.30 & 1.43 & 0.25 & 0.514 \\
\cline { 2 - 6 } $60 \%$ & stage I (F-I.FS ) & 1.80 & 1.65 & 0.22 & 0.523 \\
\cline { 2 - 6 } & stage II (I.FS - F.FS) & 1.79 & 1.89 & 0.30 & 0.537 \\
\cline { 2 - 6 } & stage III (F.FS- H) & 1.60 & 1.58 & 0.29 & 0.518 \\
\cline { 2 - 6 } & stage IV (H - D) & 1.60 & 1.50 & 0.25 & 0.510 \\
\hline \multicolumn{2}{l}{ LSD at 0.05 (season 2014$)$ is } & 0.18 & 0.06 & 0.009 & 0.013 \\
\hline
\end{tabular}


Applying the lowest irrigation regime during stage II in both seasons induced significantly the highest leaf magnesium content. Whereas, the high water regime application during stage $\mathrm{I}$ in both season induced significantly the lowest content. (Table 8).

Statistically the highest leaf zinc content was due to applying the high regime during stage II in both seasons. Reducing the applied water to the low regime during stage IV in both seasons induced significantly the lowest zinc content (table 9).
Irrigation with $60 \%$ from actual water requirements in both seasons during stage IV, induced statistically the lowest leaf manganese content. Whereas, significantly the highest leaf manganese content was attributed to applying $120 \%$ of the requirements during stage II in the first season and continuous application of $100 \%$ of the requirements during all stages (control) in the second season (table 9).

Table 9. Effect of water regime on leaf zinc and manganese content.

\begin{tabular}{|c|c|c|c|c|c|}
\hline & \multicolumn{3}{|c|}{ Zinc mg/l } & \multicolumn{2}{|c|}{ Manganese mg/l } \\
\hline $\begin{array}{l}\% \text { of actual } \\
\text { requirements }\end{array}$ & Phonological stages & 2014 & 2015 & 2014 & 2015 \\
\hline Control $100 \%$ & during all stages & 37 & 13.00 & 133 & 32.00 \\
\hline \multirow{4}{*}{$120 \%$} & stage I (F-I.FS) & 33 & 12.79 & 130 & 21.10 \\
\hline & stage II (I.FS - F.FS) & 42 & 14.34 & 160 & 30.00 \\
\hline & stage III (F.FS- H) & 41 & 13.87 & 135 & 21.00 \\
\hline & stage IV $(\mathrm{H}-\mathrm{D})$ & 41 & 13.12 & 151 & 21.50 \\
\hline \multirow{4}{*}{$80 \%$} & stage I (F-I.FS ) & 37 & 12.98 & 155 & 19.40 \\
\hline & stage II (I.FS - F.FS) & 36 & 12.71 & 125 & 19.76 \\
\hline & stage III (F.FS- H) & 35 & 12.67 & 122 & 19.50 \\
\hline & stage IV $(\mathrm{H}-\mathrm{D})$ & 37 & 12.55 & 130 & 28.00 \\
\hline \multirow{4}{*}{$60 \%$} & stage I (F-I.FS ) & 33 & 12.00 & 131 & 25.18 \\
\hline & stage II (I.FS - F.FS) & 36 & 12.24 & 150 & 21.71 \\
\hline & stage III (F.FS- H) & 34 & 12.56 & 149 & 21.77 \\
\hline & stage IV $(\mathrm{H}-\mathrm{D})$ & 32 & 11.08 & 119 & 18.92 \\
\hline \multicolumn{2}{|c|}{ LSD at 0.05 (season 2014) is } & 0.99 & 0.12 & 1.89 & 1.47 \\
\hline
\end{tabular}

With respect to leaf contents of iron and copper it was at statistically the highest magnitude when trees were irrigated with $60 \%$ of the requirements during stage II in both seasons. Whereas, increasing the applied quantities to $120 \%$ y during stage I in both season led to statistically the least contents of those nutrients significant that negatively affect (table 10).

Table 10. Effect of water regime on leaf iron and copper content.

\begin{tabular}{llllll}
\hline & \multicolumn{2}{c}{ Iron mg/l } & & Copper mg/l \\
\hline $\begin{array}{l}\text { \% of actual } \\
\text { requirements }\end{array}$ & Phenological stages & 2014 & 2015 & 2014 & 2015 \\
\hline Control 100\% & during all stages & 176.00 & 62.00 & 28.00 & 29.00 \\
\hline \multirow{5}{*}{$120 \%$} & stage I (F-I.FS) & 169.00 & 56.00 & 23.00 & 20.60 \\
\cline { 2 - 6 } & stage II (I.FS - F.FS) & 172.00 & 58.00 & 25.00 & 28.00 \\
\cline { 2 - 6 } & stage III (F.FS- H) & 171.70 & 58.10 & 25.00 & 27.00 \\
\cline { 2 - 6 } & stage IV (H - D) & 176.00 & 60.10 & 27.00 & 29.00 \\
\hline \multirow{5}{*}{$80 \%$} & stage I (F-I.FS ) & 173.00 & 60.30 & 31.00 & 31.02 \\
\cline { 2 - 6 } & stage II (I.FS - F.FS) & 181.00 & 67.00 & 30.00 & 30.10 \\
\cline { 2 - 6 } & stage III (F.FS- H) & 180.00 & 63.00 & 28.00 & 29.10 \\
\cline { 2 - 6 } & stage IV (H - D) & 181.00 & 63.50 & 31.50 & 31.00 \\
\cline { 2 - 6 } $60 \%$ & stage I (F-I.FS ) & 188.67 & 68.01 & 33.00 & 32.10 \\
\cline { 2 - 6 } & stage II (I.FS - F.FS) & 190.00 & 195.10 & 35.00 & 37.60 \\
\cline { 2 - 6 } & stage III (F.FS- H) & 188.00 & 76.00 & 33.00 & 35.30 \\
\cline { 2 - 5 } & stage IV (H - D) & 179.00 & 66.90 & 29.00 & 26.80 \\
\hline LSD at 0.05 (season 2014$)$ is & 1.25 & 1.40 & 1.02 & 1.30 \\
\hline
\end{tabular}


Variations in nutrients contents due to various regimes could be due to effect of various degrees of flooding on nutrient (Kozlowski and Pallardy, 1984), and also due to the effect of water /air ratio on nutrient absorption (Gil et al., 2012).

\section{Conclusion}

Various responses were attained when applying different regimes (percentages of water requirements) during specified phonological stages when compared with the continuous application of actual requirements. Positive effects on fruit set percentage and juice TSS\% were achieved by the application of $60 \%$ of the actual requirements during stage II which might be attributed to higher contents of leaf magnesium, iron and phosphorous this was achieved due to better absorption which might be resulting from better water /air ratio. These nutrients contribute in the synthesis of photosynthetic pigments which were evident to increase in the leaves of the stressed trees. This would lead to higher photosynthetic activity leading to the manufacture of more assimilates. There by increasing the portion for each blossom leading to an increase in fruit set. Also increase in manufactured assimilates might be the cause of increasing the juice TSS $\%$.

Also increases in fruit size went in parallel with high water supply in stage three this might be because water is essential for this developmental stage for optimal cell enlargement.

Finally further modeling studies are required to achieve highest returns for least water supplies

Altering the applied water regime to $120 \%$ of the actual requirements during stage IV induced significantly the highest yield and lowest abscission percentage. These findings might be justified that at this stage floral bud differentiation exists and that adequate water supply would increase both flowering density and quality. On the contrary statistically the highest negative effect was due to applying the highest rate during stages I for both seasons this result was obtained due to decreased potassium, phosphorus magnesium and nitrogen. Also, the seam negative effect by applying the lowest rate during stages IV this result was due to decreased zinc and manganese.

\section{References}

A.O.A.C. (Association of Official Agriculture Chemists), 1990. Official methods of analysis. 15th Ed., Washington D.C., USA.

Abd El-Messeih, W.M. and R.W. El- Gendy, 2009. Scheduling Trickle Irrigation Using Soil Matric Potential for Le Conte Pear Trees Planted in Calcareous Soils. Alex. Ssc. Exchange J., 30: 235247.

Abd El-Nasser, G. and S.M. El-Shazly, 2000. Irrigation management of Anna apple trees in relation to growth, yield, fruit quality, leaf constituents and water relation. Alex. J. Agric. Res., 45: 225-247.

Abd El-Samad, G.A., 2005. Water use, growth and productivity of some new guava strain as affected by different irrigation regimes. Egypt. J. Hort., 32: 41-56.

Ahmed, R.B., 1994. Response of pomegranate (Punica granatum L.) transplants to different soil moisture stress and growth retardant Cycocel (CCC) treatments. Ann. Agric. Sci. Moshtohor, 32: 1651-1663.

Ali, M.A., M.M. Mahmoud, A.Y. Salib, 1998. Effect of soil moisture stress on apple trees. Egypt. J Agric. Res., 76: 1565-1583.

Ali, M.M., 2006. Effect of different irrigation rates and emitter distance on vegetative growth, fruiting and water use efficiency (WUE) for Florida Prince peach cultivar trees. Egypt. J. Appl. Sci., 21: 184204.

Allen, R.G.; L.S.P. Creira; D. Raes, M. Smith, 1998. Crop evapotranspiration. Irrigation and Drainage Paper No. 56, FAO, Rome, Italy.

Behboudian, M.H. and T.M. Mills, 1997. Deficit irrigation in deciduous orchards, p. 105-131. In: Janick, J. (ed.). Horticultural Reviews Vol. 21. John Wiley \& Sons Inc., Oxford, U.K.

Behboudian, M.H., G.S. Lawes, , K.M. Griffiths, 1994. The influence of water deficit on water relations, photosynthesis and fruit growth in Asian pear (Pyrus serotina Rehd.). Scientia Horticulturae 60: 89-99.

Brandifeld, E.G. and D. Spincer. 1965. Determination of magnesium, calcium, zinc, iron and copper by Atomic adsorption spectroscopy. J. Food. Agric. Sci, 16:33-38.

Caspari, H.W., M.H., Behboudian, D.J. Chalmers. 1994. Water use, growth and fruit yield of 'Hosui' Asian pears under deficit irrigation. Journal of the American Society of Horticultural Science 119: 383-388.

Chalmers D.J.. 1989. A physiological examination of regulated deficit irrigation. $\mathrm{N} \mathrm{Z} \mathrm{J} \mathrm{Agricultural}$ Science 23:44-48.

Chalmers, D.J., G. Burge, P.H. Jerie, and P.D. Mitchell. 1986. The mechanism of regulation of 'Bartlett' pear fruit and vegetative growth by irrigation withholding and regulated deficit irrigation. J. Amer. Soc. Hort. Sci. 111:904-907

Chalmers, D.J., P.D. Mitchell, P.H. Jerie. 1984. The physiology of growth control of peach and pear trees using reduced irrigation. Acta Horticulturae 146: 143-149.

Chalmers, D.J., P.D. Mitchell, and L. van Heek. 1981. Control of peach tree growth and productivity by regulated water supply, tree density, and summer pruning. J. Amer. Soc. Hort. Sci. 106:307-312.

Channel, J.S. and R.T. Ranbirsingh. 1992. Effect of different irrigation levels on growth, cropping and 
mineral composition of mango. Acta Hort., 321: 561-565.

Cohen, A. and A. Goell, 1988. Fruit growth and dry matter accumulation in grapefruit during periods of water with holding and after reirrigation. Australian Journal of Plant. Physiology 15: 633639.

Cottenie, A.. 1980. Soils and plant testing as a basis of fertilizer recommendation. FAO Soil Bull., 3812

Crisosto C.H., R.S.Johnson, J.G.Luza, G. Crisosto, 1994. Irrigation regimes affect fruit soluble solid concentration and rate of water loss of 'O'Henry' peaches. HortScience 29:1169-1171.

Cuevas J, M.L.Cañete, V. Pinillos, A.J.Zapata, M.D.Fernández, M. González, J.J. Hueso, 2007. Optimal dates for regulated deficit irrigation in 'Algerie' loquat cultivated in Southeast Spain (Eriobotrya japonica Lindl.). Agric Water Manage 89:131-136

Dong, G. F., Z. Y. Cheng, Z. H. Zhang, X. J. Wang, X. R. Liu, R. Zhang, 2006. Effects of RDI on Water Use Efficiency and Quality of Alfalfa. Trans. CSAE, 22(5: (201-203.

dos Santos, T. P., C. M. Lopes, M. L. Rodrigues, C. R. de Souza, Ricardo-da-Silva, J. M., Maroco, J. P., J. S. Pereira and M. M. Chaves, 2007. Effects of Deficit Irrigation Strategies on Cluster Microclimate for Improving Fruit Composition of Moscatel Field-grown Grapevines. Sci. Hortic., 112: 321-330.

Duncan, D.B., 1955. Multiple range and multiple F test. Biometrics, 11: 1-24

Ebel, R.C., E.L. Proebsting, M. Patterson, 1993. Regulated deficit irrigation may alter apple maturity, quality, and storage life. HortScience. 28:141-143.

Eid T. A.; Fatama I. Abou Grah and S. M. Hussein, 2013. Effect of soil moisture regimes and potassium application on growth yield and fruit quality of "Canino" apricot (Prunus armeniaca L.) J. Plant Production, Mansoura Univ., 4 (4): 621 640.

El- Seginy, A.M., 2006. Response of Canino apricot trees to different irrigation and potassium treatments. Alex. Sci. Exchange J., 27: 64-75.

El-Azzouni, M.M., F.I. Abd El-Latif,E.A. Kenawi, 1975. Determination of maturity in pear cultivars Le-Conte, Shoubra and Pine apple. Arch. Gartenban, Berlin, 23:483-489.

FAO, 2013. Food and Agriculture Organization of the United Nations. www.fao.org.

FAO, 1998. Irrigation and Drainage Paper No. 56 Crop Evapotranspiration (guidelines for computing crop water requirements). $300 p$

Fereres E., D.A. Goldhamer, 1990. Deciduous fruit and nut trees. In: Stewart BA, Nielsen DR (eds) Irrigation of agricultural crops. Monograph, 30. A.S.A, Madison, pp 987-1017
García-Tejero I, R. Romero-Vicente, J.A. JiménezBocanegra, G. Martínez-García, V.H. DuránZuazo, J.L. Muriel-Fernández, 2010. Response of citrus trees to deficit irrigation during different phenological periods in relation to yield, fruit quality, and water productivity. Agricultural Water Management 97, 689-699.

George A.P., R.J. Nissen, 1988. The effects of temperature, vapour pressure deficit and soil moisture stress on growth, flowering and fruit set of custard apple (Annona cherimola $\times$ Annona squamosa) 'African Pride'. Scientia Horticulturae 34, 183-191.

Gercek, S., E.Boydak, M.Okant, M. Dikilitas, 2009. Water pillow irrigation compared to furrow irrigation for soybean production in a semi-arid area. Agric. Water Mange., 96 (1): 87-92.

Gil P.M., C. Bonomelli1, B. Schaffer, R. Ferreyra and C. Gentina, 2012. Effect of soil water-to-air ratio on biomass and mineral nutrition of avocado trees. Journal of Soil Science and Plant Nutrition, 2012, 12 (3), 609-630.

Girona J, M. Mata, A. Arbones, S. Alegre, J. Rufat, J. Marsal, 2003. Peach tree response to single and combined regulated deficit irrigation regimes under shallow soils. J Am Soc Hortic Sci 128:432440

Girona, J., J.Marsal, M. Mata, A. Arbones, C. Miravete, 1997. Evaluation of almond (Prunus amygdalus L.) seasonal sensitivity to water stress. Acta Hortic., 449: 489-496.

Goldhamer, D. A., 1999. RDI for California Canning Olives. Acta Hortic. Sin., 474: 369- 372

Goldhamer, D. A., M. Viveros, M. Salinas, 2006. Regulated Deficit Irrigation in Almonds: Effects Variations in Applied Water and Stress Timing on Yield and Yield Components. Irrigation Sci., 24(2): 101- 114.

Greamer, J.R. and R.M. Bostock, 1986. CXharacterization and biological activity of phytophthora intestans phospholipids in hyper sensitive response of poatato tuber. Physiol. Mol. Plant Pathol. 28:215-225.

Holzapfel, H.E.; G.G. Figueroa; V.A. Venegas and C.R. Matta, 1995. Water requirements in mature apple trees. Agro- Ciencia ii (1) : 49- 54.

Hossein B. M., G. Stephen Lawes Hsiao, 1993. Fruit quality in 'Nijisseiki' Asian pear under deficit irrigation: physical attributes, sugar and mineral content، and development of flesh spot decay. New Zealand Journal of Crop and Horticultural Science, 1994, Vol. 22: 393-400.

Hsiao T.C., 1993. Growth and productivity of crops in relation to water stress. Acta Horticulturae, 335:137-148.

Hussein, S.M.M., 2004. Effect of Different Irrigation Levels on the Le-Cont Pear Trees. Ph.D. Thesis Fac. Agric. Hort. Dept., Cairo Univ., Egypt, pp: 175. 
Jackson MB, T.D Colmer, 2005. Response and adaptation by plants to flooding stress. Ann. Bot. 96:501-505.

Jackson, M. L., 1973. Soil Chemical Analysis, Prentice Hall of India (P) Ltd., New Delhi.

Jackson, N.L., 1958. Soil Chemical Analysis. Constable. Ltd. Co., London 498p.

Jivan, C., F. Sala, 2014. Relationship between tree nutritional status and apple quality. Hort. Sci. (Prague) Vol. 41, No. 1: 1-9

Kandil, E.A. and U.S. El-Feky, 2006. Effect of soil matric potential on Canino apricot trees in sandy soil under drip irrigation. J. Agric. Sci. Mansoura Univ., 31(9): 5867-5880.

Karmeli and Keller, 1975. Irrgation design. MFg. Co., Glendora, Calif., p. 193.

Khalil, H.A.H. 2004. Regulated Deficit Irrigation in Picual Olive Trees for Oil Production. M.Sc. Thesis, Fac. of Environ. Agric. Sci. Hort. Dept. ElArish, Suez Canal Univ. Egypt, pp: 146.

Khattab Magda M., A. E. Shaban, Arafa H. ElShrief and A. S. El-Deen Mohamed, 2011. Growth and Productivity of Pomegranate Trees Under Different Irrigation Levels. II: Fruit Quality. Journal of Horticultural Science \& Ornamental Plants 3 (3): 259-264.

Kozlowski, T.T., Pallardy, 1984. Effects of flooding on water, carbohydrate and mineral relations. In: Flooding and plant growth. T.T. Kozlowski (ed.). Academic Press, Orlando, Florida, USA, pp. 165193.

Kramer, P. J. and J. S. Boyer, 1995. Water relations of plants and soils. Academic Press. Ed. T.T. Kozlowski. Academic Press, Orlando, FL, pp 165--193.

Kramer, P.J., 1983. Water deficits and plant growth. pp: 342-389. In: P.J. Kramer (ed.). Water relations of plants. Academic Press, New York.

KÜÇÜKYUMUK C., E. Kacal, H.Yildiz, 2013. Effects of Different Deficit Irrigation Strategies on Yield, Fruit Quality and Some Parameters: 'Braeburn' Apple Cultivar. Not Bot Horti Agrobo, 2013, 41(2):510-517.

Kuroda H., Y. Nishiyama, F. Nakajima, 1985. Effect of soil moisture on seasonal patterns in freezing resistance of apple trees. In: Research Bulletin. Hokkaido National Agricultural Experiment Station, Hokkaido, 29-41pp.

Lawand, B.T. and V.K. Patil, 1996. Effect of different water regimes on fruit quality of pomegranate (Punica granatum L.). Inter. J. Tropical Agric., 14: 153-158.

Le, SH; J.G. Huguet, P.G. Schoch, P. Orlando, 1989. Responses of peach tree growth and cropping to soil water deficit at various phonological states of fruit development. J. Hortic., Sci., 64: 541-552.

Li, S. H., 1993. The Response of Sensitive Periods of Fruit Tree Growth, Yield and Quality to Water
Stress and Water Saving Irrigation. Plant Physiol. Commun., 29(1:) 10-16.

Li, S.-H., J.-G. Huguet, P.G. Schoch, P. Orlando, 1989. Response of peach tree growth and cropping to soil water deficit at various phenological stages of fruit development. J. Hort. Sci. 64:541-552.

Liao C.T., C.H. Lin, 2001. Physiological adaptation of crop plants to flooding stress. Proc. Natl. Sci. Counc. 25:148-157.

Lichtenthaler, H.K., 1987. Chlorophylls and carotenoids: Pigments of photosynthetic biomembranes. Methods Enzymol. 148:350-382.

Liu, M. C., T. Kojima, M. Tanaka, H. Chen, 2001. Effect of Soil Moisture on Plant Growth and Fruit Properties of Strawberry. Acta Hortic. Sin., 28(4): 307-311.

Manjula V. Nathan, 2009. Soils, Plant Nutrition and Nutrient Management. University of Missouri Extension. MG4 Soils, Plant Nutrition and Nutrient Management. http://extension.missouri. edu/p/MG4

Marsal, j., H. F. Rapoport, T. Manrique, and j. Cirona, 2000. Pear fruit growth under regulated deficit irrigation in container-grown trees; Scientia Hort. 85:243-259.

Mengel, K. and E. A. Kirkby (1982). Principal of plant nutrition. Bern. Switzerland. Int. Potash Inst., P. 520.

Mensah JK, B.O. Obadoni, P.G. Eroutor, F. Onome-Irieguna, 2006. Simulated flooding and drought effects on germination, growth and yield parameters of Sesame (Seasamum indicum L.). Afr. J. Biotechnol., 5: 1249-1253.

Mikhael, G.B. and A.A. Mady, 2007. Effect of some drip irrigation and mulching treatments on: II. Yield, fruit quality and water use efficiency of Anna apple trees grown in new reclaimed soils. Minufiya. J. Agric. Res., 32: 1175-1191.

Mills T.M., M.H. Behboudian, B.E. Clothier, 1996. Water relations, growth, and the composition of 'Braeburn' apple fruit under deficit irrigation. J Am Soc Hortic Sci 121:286-291.

Mitchell, P.D., B. van den Ende, P.H. Jerie, and D.J. Chalmers, 1989. Responses of 'Bartlett' pear to withholding irrigation, regulated deficit irrigation, and tree spacing. J. Amer. Soc. Hort. Sci. 114:15-19

Mitchell, P.D., D.J. Chalmers, P.H. Jerie, and G. Burge, 1986. The use of initial withholding of irrigation and tree spacing to enhance the effect of regulated deficit irrigation on pear trees. J. Amer. Soc. Hort. Sci. 111:858-861.

Mitchell, P.D., P.H. Jerie, and D.J. Chalmers, 1984. The effects of regulated water deficits on pear tree growth, flowering, fruit growth, and yield. J. Amer. Soc. Hort. Sci. 109:604-606.

Mpelasoka, B.S., M.H. Behboudian, S.R. Green, 2000. Effects of irrigation regime and crop load on water use and yield of 'Braeburn' apple grown in lysimeters. Acta Horticulturae 537:741-748. 
Naor A, R. Stern, M. Peres, Y. Greenblat, Y.Gal, M.A. Flaishman, 2005. Timing and severity of postharvest water stress affect following-year productivity and fruit quality of field-grown 'Snow Queen' nectarine. J Am Soc Hortic Sci 130:806-812

Nikbakht J., M. Thaeri and M. Sakkaki, 2011. Effect of Continuous Deficit Irrigation on Yield and Quality of Koroneiki Olive (Olea europaea L.) Cultivar," 21st International Congress on Irrigation and Drainage, Teheran, pp. 356-364.

Piper, C.S., 1950. Soil And Plant Analysis. Inter. Sci., Pulb, New York, pp. 368.

Pirzad, A. and M. Razban, 2011. Effect of different rates of superabsorbent under different irrigation regimes on growth and (Matricaria chamomilla), German chamomile tolerance to water deficit in the second culture. Journal of Sustainable Agricultural Production, 21(4): 123- 137.

Plummer, D.T., 1971. An introduction to practical biochem. Published by Mc Graw Hill Book Company(U.K.) Limited.

Robert, C. E. and L. P. Edward, 1993. Regulated Deficit Irrigation May Alter Apple Maturity, Quality, and Storage Life. J. Hort. Sci., 28(2): 141143.

RUIZ-SÁNCHEZ M.C., J. EGEA, R.GALEGO, A. TORRECILLAS, 1999. Floral biology of Búlida apricot trees subjected to postharvest drought stress. Ann Appl Biol 135, 523-528.

Shailendra, A. and N. Agrawal, 2005. Effect of trickle irrigation on growth, yield and quality of pomegranate (Punica granatum) cv. Ganesh in Chhattisgarh Region. Mysore J. Agric. Sci., 39: 175-181.
Smith, N., 1991. "CROPWAT" model for Eto calculation using Penman Monteith Method. FAO, Rome, Italy.

Snedecor, G. W. and W. G. Cochran, 1980. Statistical methods. The 7 th ed the Iowa state Univ. Press Iowa, U.S.A. P. 593.

Taylor, J.E., C.A. Whitelaw, 2001. Signals in abscission. New Phytologist، 151(2), pp. 323339.

Torrecillas, A., A. Domingo, R. Galego, and M. C. Ruiz-Sanchez, 2000. Apricot tree response to withholding irrigation at different phenological periods. Scientia Hort. 85:201-215.

Tripathi SK, A.P Sane., P.Nath, N. Tuteja, 2008. Organ abscission in plants: Understanding the process through transgenic approaches. In: RiveraDominguez M, Troncoso-Rojas R, TiznadoHernandez ME, editors. A transgenic approach in plant biochemistry and physiology, Research Signpost, 155-180.

Vernon, L.P. , G.R. Selly, 1966. The chlorophylls. Academic press. New York and London.

Verreynne, J. S., E. Rabe, K. I. Theron, 2001 The Effect of Combined Deficit Irrigation and Summer Trunk Girdling on the Internal Fruit Quality of 'Marisol' Clementines. Sci. Hort., 91: 25-37.

Wardlaw, I. F., 1990. The control of carbon partitioning in plants. Tansley Review No. 27. New Phytol. 116: 341-381.

Westwood, M. N., 1993. Temperate-zone pomology. Timber Press, Inc

Westwood, M.N., H.O. Bjornstad, 1978. Winter rainfall reduces rest period of apple and pear. J. Amer. Soc., 103: 142-144. 


\section{تأثير مستويات الري خلال المراحل الفينولوجية المختلفة على المحصول وخصائصه للكمثرى الليكونت}

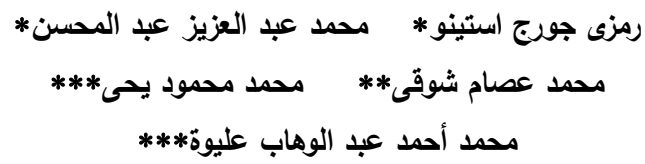

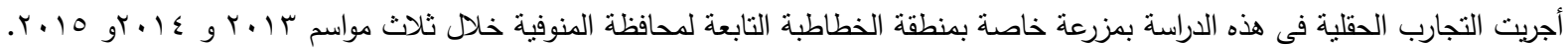

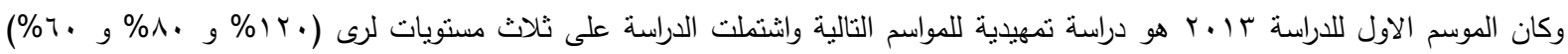
بالاضافة الى الاحتياج المائى . . 1\% خلا اربع مراحل فينولوجية مختلفة وهى المرحلة الاولى وهى من بداية التزهير الى العقد النهائى والمرحلة

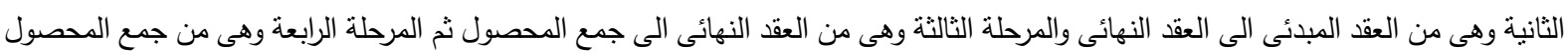

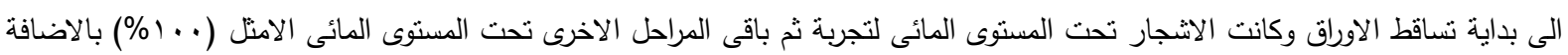

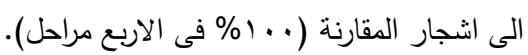
كانت القياسات المؤخوذة : نسبة العقد و نسبة التساقط والمحصول والصفات الثهرية الثرات ( وزن الثمرة والصلابة ونسبة المواد الصلبة الذائبة والحموضة) والقياسات الكيميائية محتوى الاوراق من العناصر الغذائية ( النيتروجين والفوسفور والبوتاسيوم والماغنسيوم والحديد والزنك والمنجنيز والنحاس) ومحتوى الاوراق من الكلورفيل أ وب والكاروتينات). اظهرت نتائج الدراسة زيادة نسبة العقد عند المستوى المائى . ؟\% خلال المرحلة الثانية وانخفاض نسبة التساقط وزيادة المحصول بزيادة الاحتباج

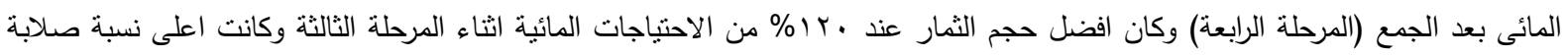
ونسبة المواد الصلبة الذائبة بالثمار بتقليل الاحتياجات المائية فى اى مرحلة وكان اعلى محتوى للاوراق من النيتروجين عند اعلى مستوى مائى النى

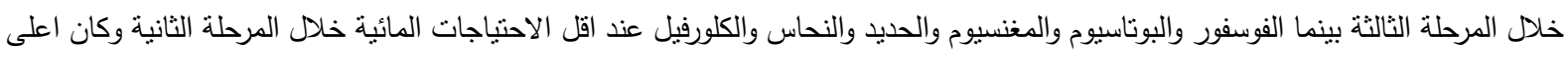
محتوى لزنك والمنجنيز بزياة الاحتباج المائى خلال المرحلة الثانية.

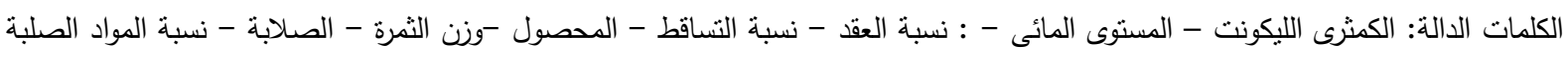
الذائبة - الحموضة - النيتروجين - الفوسفور - البوتاسيوم - الماغنسيوم - الحديد -- الزنك- المنجنيز والنحاس - الكلورفيل أ وب - الكاروتبنات 